\title{
ANALISIS PENYAJIAN PROGRAM TALK SHOW “ASSALAMUALAIKUM INDONESIA” DI SALAM TV MEDAN
}

\author{
Sri Wahyuni \\ Prodi Televisi dan Film Universitas Potensi Utama \\ sriwahyuni2909@gmail.com
}

\begin{abstract}
ABSTRAK
Televisi saat ini sangat popular dikalangan masyarakat baik pada masyarakat perkotaan hingga pedesaan. Televisi juga sangat berperan dalam perubahan fenomena yang menciptakan budaya baru bagi masyarakat seperti masyarakat dapat menghabiskan waktu luang untuk melihat televisi. Perubahan ini juga terjadi begitu pesat dengan mengikuti perkembangan teknologi informasi seperti Internet. Pengaruh internet berkembang semakin cepat dan pesat dalam penyebaran informasi di seluruh dunia dan salah satu yang sedang trend dikalangan masyarakat menggunakan internet yaitu live streaming video melalui Youtube yang merupakan proses pengiriman data/informasi berupa audio visual secara terus menerus melalui internet secara langsung. Program Acara Assalamualaikum Indonesia juga mempergunakan youtube sebagai salah satu strategi dalam penyiarannya. Selain itu, 13 strategi kreatif digunakan dalam melakukan penelitian program Assalamualaikum Indonesia seperti : target penonton, bahasa naskah, format acara, puncing line, gimmick dan funfare, clip hanger, tune \& bumper, penataan artistic, music \& fashion, ritme dan birama acara, log dan music track untuk ID tune, General Rehearsal, interactive program serta menggunakan penelitian deskriptif kualitatif.
\end{abstract}

Kata kunci: Talk Show, Assalamualaikum Indonesia, Salam Tv Medan

\section{ABSTRACT}

Television is currently very popular among the public both in urban and rural communities. Television is also very instrumental in changing the phenomenon that creates a new culture for the community as society can spend leisure time looking at television. This change also happened so rapidly by following the development of information technology such as the Internet. The influence of the internet is growing faster and faster in the dissemination of information throughout the world and one of the trends among the public is using the internet namely live streaming video via Youtube which is the process of sending audio / visual data / information continuously through the internet directly. The Assalamualaikum Indonesia Program also uses YouTube as a strategy for broadcasting. In addition, 13 creative strategies were used in conducting research programs at Indonesian Salamalam such as: target audience, script language, program format, puncing line, gimmick and funfare, clip hanger, tune \& bumper, artistic, music \& fashion arrangement, rhythm and program time, log and music track for ID tune, General Rehearsal, interactive program and using qualitative descriptive research.

Keywords: Talk Show, Creative Strategy, Assalamualaikum Indonesia, Salam Tv Medan

\section{PENDAHULUAN}

Televisi saat ini sangat popular dikalangan masyarakat baik pada masyarakat perkotaan hingga pedesaan. Hal ini dapat dilihat dengan keberadaan televisi di rumah-rumah, tokotoko, perkantoran dan yang lainnya. Oleh karena itu, dalam penyebaran informasi ataupun 
berita-berita lebih mudah dan cepat tersampaikan ke masyarakat. Televisi juga dapat dikatakan sebuah produk teknologi informasi yang memiliki banyak perkembangan sejak konsepnya dikemukakan Paul Nipkow di Jerman pada tahun 1884. Pada tahun 1928 seorang berkembangsaan Amerika Serikat yaitu Vladmir ZworkyN telah menemukan tabung kamera iconoscope yang dapat berfungsi menangkap dan mengirimkan gambar melalui sebuah kotak yang diberikan nama Televisi. Kemudian televisi mengalami kemajuan dalam estetika gambarnya yaitu dari layar hitam putih menjadi layar berwarna (Morissan, 2011:7).

Televisi juga sangat berperan dari perubahan fenomena yang terjadi di masyarakat saat ini karena mampu menciptakan budaya masyarakat yang baru seperti masyarakat dapat menghabiskan waktu luang bahkan meninggalkan pekerjaannya untuk melihat tayangan yang disukai. Teknologi yang juga semakin memberikan kemudahan sangat berperan terhadap perkembangan televisi karena dengan adanya kemudahan tersebut membuat televisi lebih dapat mudah dinikmati. Masyarakat tidak hanya melihat sebuah tayangan televisi di suatu tempat melainkan dengan mudah dilihat hanya dengan menggunakan handphone yang terintegrasi melalui internet.

Pengaruh internet berkembang semakin cepat dan pesat dalam penyebaran informasi di seluruh dunia dan salah satu yang sedang trend dikalangan masyarakat menggunakan internet yaitu live streaming video melalui Youtube yang merupakan proses pengiriman data/informasi berupa audio visual secara terus menerus melalui internet secara langsung. Para pengguna dapat menonton video dan dapat menyiarkan video secara langsung maupun tidak langsung yang dapat dilihat oleh seluruh masyarakat. Media penyiaran dengan platform digital memiliki banyak kelebihan dibandingkan media analog atau konvensional. Selain itu, media baru era informasi memiliki performa kualitas tayangan serta sebaran yang lebih luas.

Pengaruh yang sangat besar didapat melalui youtube membuat Salam Tv Medan memanfaatkan youtube sebagai salah satu penyajian dalam menyiarkan program acaranya. Salam Tv medan merupakan stasiun televisi swasta yang berlokasi di Medan Sumatera Utara dan memiliki misi Layanan informasi yang bersih (terpercaya), Islami dan berbahasa Indonesia. Selaras dengan misinya, Salam Tv berkomitmen ingin menjadi televisi pilihan pertama bagi umat islam karena menyajikan program-program acara membahas mengenai islam seperti salah satu program acaranya Assalmualaikum Indonesia. Namun, tidak semua lapisan masyarakat dapat menikmati siaran yang disajikan Salam Tv medan, dikarenakan Salam Tv masih menggunakan antenna Parabola agar dapat menjangkaunya. Untuk itu, Salam Tv dapat memanfaatkan Youtube sebagai penyajian dalam program acaranya. Selain itu strategi kreatif digunakan dalam penayangan program acara agar masyarakat tertarik melihat program acara tersebut. Strategi kreatif merupakan rencana khusus dalam penentuan ide-ide kreatif seperti terobosan-terobosan baru agar tercapainya suatu tujuan. Hal ini telah diungkapkan oleh Kasali mengenai strategi kreatif bagi stasiun televisi yang merupakan orientasi pemasaran yang diberikan kepada orang-orang kreatif dalam membuat suatu program (Kasali. 2007:77).

Untuk menggungkap penyajian program acara Assalamualaikum Indonesia maka peneliti menggunakan metode penelitian deskriptif kualitatif. Hal ini berfungsi agar hasil analisis yang dilakukan dapat diinterprestasikan dengan jelas. Selain itu, Landasan teori yang digunakan menggunakan 13 elemen strategi kreatif dari Naratama dalam memproduksi acara televisi yaitu : target penonton, bahasa naskah, format acara, puncing line, gimmick dan funfare, clip hanger, tune \& bumper, penataan artistic, music \& fashion, ritme dan birama acara, log dan music track untuk ID tune, General Rehearsal, interactive program (Naratama, 2013:125). 


\section{STUDI LITERATUR}

Beberapa tulisan yang telah dijadikan rujukan atau referensi penulis dalam penelitian ini adalah sebagai berikut:

Tulisan Febfi Setyawati (2014) dalam skripsinya yang berjudul "Analisis Program Drama "Jtoku" pada Televisi Internet Layaria Tv". Skripsi ini mengenai membahas mengenai bagaimana bentuk program drama jtoku dan manajemen dalam produksi program drama tersebut. Dari pembahasan yang telah dipaparkan dapat disimpulkan bahwa dalam mengatur sumber daya pada program drama jtoku terdiri dalam beberapa tahapan yaitu : 1) Man (sumber daya manusia), Crew Jtoku dalam proses produksi berkemampuan multiskilled; 2) Money: Pengaturan anggaran dana dalam produksi Jtoku menggunakan financial oriented dimana teknik peraturan keuangan yang dibatasi ketersediaannya dana; 3 ) Material : material atau bahan mentah dalam produksi program drama adalah ide cerita. Ide cerita Jtoku terinspirasi dari teknik pembuatan cerita superhero Jepang dan Amerika dan diaplikasikan pada konten local yang berkembang di Indonesia; 4) Methode : merupakan cara produksi program Jtoku sesuai dengan standar operasional prosedur (SOP) membuat program drama mulai dari praproduksi, produksi hingga pasca produksi; 5) Machine : Alat yang digunakan dalam memproduksi program drama tersebut kamera DSLR dan perekam suara digital, lighting portable; 6) Market : target sasaran program Jtoku terbagi atas tiga kualifikasi yaitu Demografis, Geografis dan Geodemografis; 7) Minute: Perencanaan waktu yang digunakan untuk produksi program Jtoku. Berdasarkan elemen naratif dan sinematik dapat disimpulkan 1) Dominasi close up: jumlah shot close up pada program Jtoku mendominasi; 2) Inductive Sequencing : digunakan karena banyaknya penggunaan shot close up; 3) Durasi : Durasi digunakan karena keadaan Indonesia yang memiliki koneksi internet yang lambat dan berbayar; 4) Dense audio track : terdiri dari dialog, sound effect dan musik ilustrasi. Berdasarkan korelasi antara bentuk dan manajemen produksi program drama jtoku yaitu 1) Penggunaan Shot close up : yang mendominasi program mendukung manajemen man, money, machines dan minute; 2) Penggunaan inductive sequencing : mendukung dalam bidang minute; 3)Durasi: mendukung dalam bidang man, money, minute; 4)Dense audio track: membantu dalam bidang machine. Persamaan penelitian ini terletak kepada tahapan dalam menganalisa program televisi yang proses dalam penyiarannya samasama memanfaatkan youtube namun terdapat pula perbedaan yang mendasar dengan penelitian ini yang terletak kepada program acara yang dibahas serta dengan hasil yang diperoleh melalui penelitian sangatlah jauh berbeda dengan penelitian yang dirancang.

Selanjutnya tulisan Triadi Sya'dian (2017) dalam tesis yang berjudul : "Ideologi Salam Tv Medan dibalik Tayangan Youtube". Tesis tersebut menjelaskan proses identifikasi bentuk program acara dan ideology Salam Tv dalam pemanfaatan media social youtube. Data yang dikumpulkan menggunakan penelitian kualitatif yang meliputi observasi, wawancara, jurnal atau buku. Kerangka teoritis dibangun berdasarkan pengamatan dan data yang diperoleh dari lapangan kemudian disesuaikan dengan objek penelitian yaitu youtube. Untuk membongkar kenyataan yang ada di Salam Tv digunakan teori Globalisasi agar mengetahui tampilan tayangan Youtube. Aliran globalisasi adalah etnoscape, ideoscep, financescap, mediascape dan tecnoscape yang kemudian mengungkap bentuk tayangan program acara salam Tv pada youtube dengan menggunakan teori Bentuk Greamme Burton. Hasil yang didapat dari penelitian ini adalah perubahan bentuk tayangan program Salam Tv di Youtube. Perubahan ini dibentuk berdasarkan kebutuhan pemirsa untuk meningkatkan rating program acara Salam Tv. Program acara tidak langsung (live) akan disajikan secara terpisah dan tersendiri sesuai dengan judul perigram serta sesuai dengan episode. Episode yang telah dipecah menjadi satu video di upload ulang ke saluran Toutube sehingga pemirsa dapat dengan mudah memilih episode yang ingin mereka tonton. 
Identitas Tv di youtube menghasilkan ideology islam didukung oleh ideology komersil, social dan politik simultan secara bersamaan.

Kemudian tulisan Lia permata sari (2012) dalam tesisnya "Optimalisasi Penggunaan

Video Youtube untuk Meningkatkan Keterampilan Berbicara Siswa dalam Menggunakan Fungsi Bahasa. Tesis ini telah mengidentifikasi seberapa jauh Youtube meningkatkan ketrampilan berbicara siswa dalam menggunakan bahasa dan menggambarkan keadaan kelas ketikavideo Youtube diaplikasikan dalam kelas bahasa inggris. Temuan hasil penelitian adalah video Youtube dalam pembelajaran bahasa inggris dapat meningkatkan keterampilan berbicara siswa dan kondisi kelas pada pembelajaran fungsi bahasa inggris. Penelitian ini memberikan kontribusi berupa gambaran pemanfaatan media social youtube sebagai media pembelajaran. Persamaan dengan penelitian ini yaitu pemanfaatan teknologi social media yaitu youtube sedangkan perbedaannya terletak kepada jenis kajian yang dilakukan yaitu peningkatan keterampilan berbahasa inggris sedangkan penelitian ini mengkaji pada sajian program acara tersebut.

\section{PEMBAHASAN}

Salam Tv medan merupakan stasiun televisi swasta yang telah resmi mengudara pada tanggal 1 April 2016 setelah sebelumnya menjalani siaran percobaan sejak tanggal 1 September 2015. Salam Tv didirikan dengan membawa semangat dakwah dilingkungan keluarga karena keluarga merupakan dasar bangunan masyarakat dan barometer maju mundurnya sebuah akhlak serta pembentukan karakter. Keluarga juga berperan penting dalam membentengi diri untuk menghadapi berbagai ancaman dari pengaruh media yang negatif. Berangkat dari penjelasan tersebut, maka salam tv menjadikan keluarga target yang menjadi akar rumput masyarakat dalam bentuk tauladan, dukungan dan pengembangan (salamtv.info : diakses pada tanggal 12 November 2017, pukul 20.00). Adapun logo Salam Tv adalah sebagai berikut :

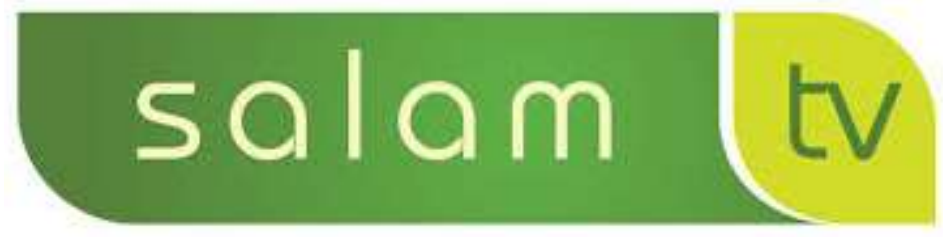

Gambar 1. Logo Salam TV

(Sumber : salamtv.info.2017)

Salam TV memiliki beberapa program acara salah satunya adalah program acara Assalamualaikum Indonesia. Assalamualaikum Indonesia merupakan salah satu program acara unggulan Salam Tv yang ditayangkan setiap hari senin sampai dengan sabtu pukul 10.00 WIB. Program acara tersebut berdurasi 60 menit dan selalu menyajikan cerita-cerita yang inspiratif bagi keluarga muslim. 


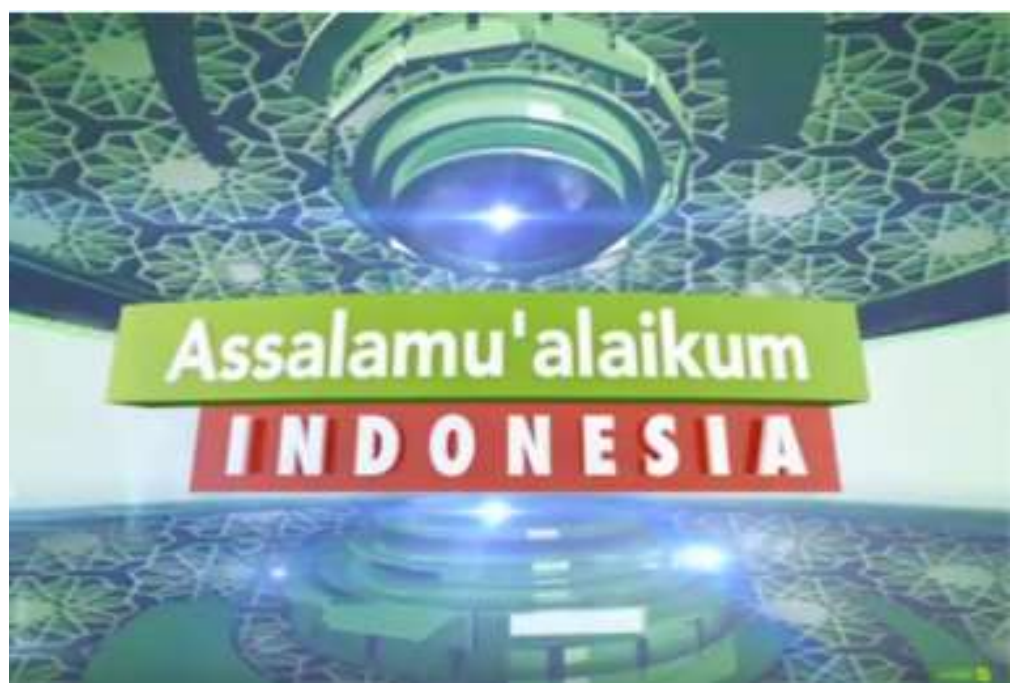

Gambar 2. Program Acara Assalamualaikum Indonesia

(Sumber : Capture Canel Youtube Salam Tv.2017)

Program acara Assalamualaikum Indonesia memiliki 4 segmen dalam proses penayangannya. Dimana terdapat narasumber yang dihadirkan pada segmen 2 dan segmen 3. Adapun strategi kreatif dalam program acara Assalamualaikum Indonesia sesuai dengan 13 elemen adalah sebagai berikut:

\section{Target Penonton}

Dalam menentukan target penonton diperlukan metode penelitian dengan memahami 3 faktor klasifikasi target penonton yaitu usia, jenis kelamin dan status social. Dari ketiga klasifikasi tersebut maka akan ditemukan karakter penonton dari program acara tersebut sehingga karya yang dibuat mendapat jaminan akan sukses dan disukai oleh pemirsanya (Naratama. 2013:125). Target penonton pada program acara Assalamualaikum Indonesia disesuaikan dengan visi dan misi dari Salam Tv yaitu untuk sahabat keluarga muslim Indonesia. Dengan kata lain, sasaran dari program acara tersebut adalah usia dewasa. Namun demikian, karena program acara ini membahas mengenai peristiwa-peristiwa atau isu-isu yang terjadi saat ini maka program ini juga disukai oleh penonton usia muda, terlebih program acara ini dapat dinikmati di canel youtube yang dapat menjangkau luas masyarakat.

\section{Bahasa Naskah}

Bahasa naskah biasanya digunakan dalam naskah drama dan nondrama yang kemudian disesuaikan dengan target audiens dari program acara tersebut. Bahasa naskah pada program acara Assalamualaikum Indonesia menggunakan bahasa yang lebih santai, sopan dan terkadang terkesan sedikit formal karena menjunjung konsep islami. Bahasa naskah ini dapat mudah dipahami dan dimengerti oleh sahabat keluarga muslim di Indonesia karena memiliki tutur bahasa yang baik ketika memberikan informasi-informasi disetiap episode nya. Pada dasarnya, bahasa yang digunakan dalam program acara Assalamualaikum Indonesia adalah dialog karena program acara ini memang berupa program talkshow yang setiap episodenya mengundang masing-masing narasumber. Adapun bahasa naskah pada dialog yang terdapat pada episode "Berdakwah Lewat Karya Film Pendek" seperti sebagai berikut:

a. Segmen pertama diawali dengan opening program Assalamualaikum Indonesia kemudian sambutan dari pembawa acara sebanyak 2 host. Sebagai pembuka kedua 
host memberikan ucapan salam kepada seluruh pemirsa yang dilanjutkan dengan pembacaan topik mengenai "Kabar Untuk Anda". Pada segmen pertama ini belum terdapat bintang tamu / narasumber yang masuk di program tersebut. Akan tetapi, kedua host memberikan informasi-informasi terkini dalam hal ini mengenai topik social media. Keaktifan dari kedua host sangat ditekankan dalam menyampaikan informasi-informasi, improvisasi dan lain sebagainya pada program Assalamualaikum Indonesia agar informasi yang disampaikan dapat dipahami oleh pemirsa dirumah. Pada segmen ini bahasa naskah yang digunakan cenderung menggunakan full dialog antara host 1 dengan host 2 karena pada segmen pertama ini penyampaian informasi yang bersifat umum kepada seluruh masyarakat dirumah.

b. Pada segmen kedua sama seperti segmen pertama diawali dengan salam pembuka terlebih dahulu oleh kedua host serta memberitahukan mengenai channel Salam Tv kemudian membahas mengenai bintang tamu yang akan datang. Host juga menyampaikan mengenai pokok pembahasan yang akan dibincangkan dengan bintang tamu sebagai informasi bagi penonton. Selain itu, dialog yang disampaikan pada host 1 dengan host 2 saling mengisi satu sama lain untuk menghindari kekosongan pada program tersebut. Hal ini dikarenakan, program talkshow akan berjalan dengan baik jika host dapat membawakan suasana dalam program tersebut.

c. Sama hal nya dengan segmen kesatu dan kedua, segemen ketiga ini juga dibuka dengan salam pembuka oleh host yang dilanjutkan dengan bincang-bincang dengan narasumber yaitu 2 orang pembentuk PH (Production House) dari Fisabilillah Production. Bincang-bincang tersebut di pandu oleh salah satu host saja, sementara host yang kedua tidak ikut dalam segmen ketiga tersebut. Bahasa naskah yang digunakan oleh segmen ketiga ini cenderung menggunakan dialog tanya jawab anatara narasumber dan hostnya. Hal yang diperbincangkan seputar history dari Fisabilillah Production sendiri yang dapat menginspirasi sahabat muslim di Indonesia. Dalam penjelasan narasumber dapat disimpulkan bagaimana mereka berdakwah melalui sebuah audio visual (film) agar dapat mudah diterima oleh masyarakat.

d. Pada segmen keempat sama seperti episode Assalamualaikum Indonesia lainnya, kedua host memberikan tips dan trik untuk sahabat keluarga muslim di Indonesia sebelum menutup atau mengakhiri program tersebut. Tips dan Trik tersebut mengenai "Tips agar tempat kerja selalu rapi dan nyaman". Bahas.a naskah yang digunakan masih sama seperti segmen-segmen sebelumnya yaitu dialog yang digunakan oleh kedua host tersebut. Meskipun terkesan formal namun bahasa naskah yang digunakan lebih bersifat ringan dan mudah diterima oleh masyarakat. 


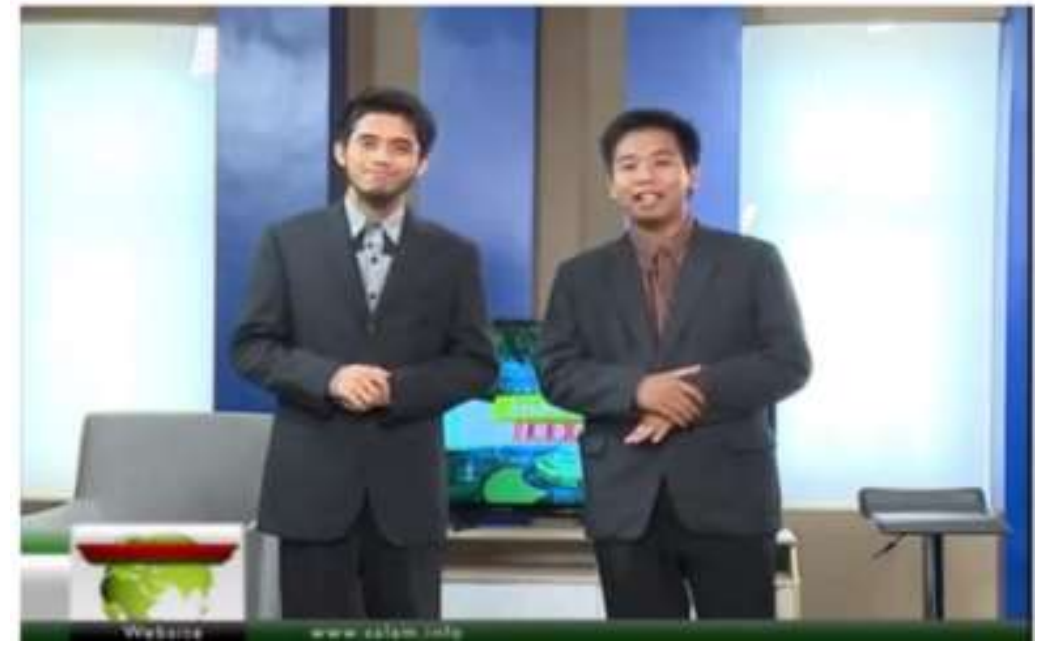

Gambar 3. Pembawa Acara Assalamualaikum Indonesia (Sumber : Capture Canel Youtube Salam Tv.2017)

\section{Format Program}

Format program Assalamualaikum Indonesia merupakan program acara talkshow yaitu sebuah program acara yang mengumpukan beberapa orang untuk mendiskusikan mengenai beberapa isu atau topic yang menarik untuk diperbincangkan. Program tersebut biasanya akan dipandu oleh moderator/host sebagai pemandu acara yang sedang ditayangkan. Program acara talkshow juga kadangkala menghadirkan narasumber untuk berbagi informasi, pengalaman dan lainnya yang dapat bermanfaat bagi pemirsa/penonton yang ada di rumah. Menurut Naratama didalam program talkshow berbicara menjadi sesuatu hal yang sangat penting atau kebutuhan primer sedangkan tata panggung, dekorasi kostum dan lain sebagainya merupakan kebutuhan sekunder (Naratama, 2013:163).

Maka dari itu program Assalamualaikum Indonesia selalu menonjolkan dialog-dialog tanya jawab dengan menghadirkan berbagai narasumber. Namun, dalam episode "berdakwah lewat karya film pendek" tidak menampilkan format talkshow yang utuh, melainkan terkesan memberikan one way information yang berarti host hanya mewawancari seorang narasumber dalam beberapa waktu sekitar 24 menit yang isi pembahasannya akan dijawab lurus oleh narasumber tersebut tanpa ada counter back dari host tersebut. Hasilnya, pada pembahasan tersebut terkesan monoton, kaku dan kurang kreatif sehingga penonton akan merasa bosan. Meskipun demikian, Program Assalmualaikum Indonesia adalah program talkshow yang berbeda dari program-program lainnya karena selain menghadirkan narasumber, host memberikan informasi-informasi lain di awal segmen dan di akhir segmen yang disuguhkan sehingga penonton akan mendapatkan banyak informasi dari program acara tersebut.

\section{Punching Line}

Punch Line sendiri merupakan surprise atau kejutan-kejutan dalam dialog naskah yang sengaja dituliskan dan dimainkan oleh pemain sehingga dapat menghentak perhatian penonton yang mulai jenuh dan bosan. Dalam program Assalamualaikum Indonesia sendiri punch line digunakan di setiap awal segmen dengan mengucapkan nama program sebelum masuk ke pembahasan. Selain itu, host juga sering melanjutkan kalimat sapaan "Sahabat Muslim Indonesia" di berbagai dialog sesuai dengan target audiensi dan visi dari Salam Tv sendiri. Merujuk kepada pengertian punc line yaitu berupa komedi, celetukan, tangisan dan lain sebagainya. Peneliti menemukan bahwa program Assalamualaikum Indonesia belum menerapkan punch line sesuai dengan pengertian teorinya. Namun, program 
Assalamualaikum Indonesia telah menggantikannya dengan hal yang lainnya seperti dialog sapaan di setiap awal segmen atau ditengah-tengah segmen dan pemberian informasi lain selain yang diberikan narasumber. Hal ini digunakan untuk menghindari kebosanan atau kejenuhan pada penonton. Informasi tersebut pun sangat variatif dan mengikuti isu-isu yang sedang berkembang di lingkungan sehari-hari masyarakat.

\section{Gimmick and Funfare}

Gimmick merupakan cara yang digunakan untuk mendapatkan perhatian penonton dapat berupa candaan, atau sound effect. Sedangkan funfare merupakan puncak acara yang dimeriahkan oleh keceriaan, kemewahan, keindahan dan kebersamaan (Naratama, 2013:127). Gimmick sendiri pada dasarnya selalu digunakan pada setiap program acara indoor ataupun outdoor, namun pada program acara indoor gimmick lebih sering digunakan untuk menghibur penonton agar tidak bosan. Pada program Assalamualaikum Indonesia gimmick pun dilakukan oleh kedua host disela-sela materi/informasi yang disampaikan kepada penonton.

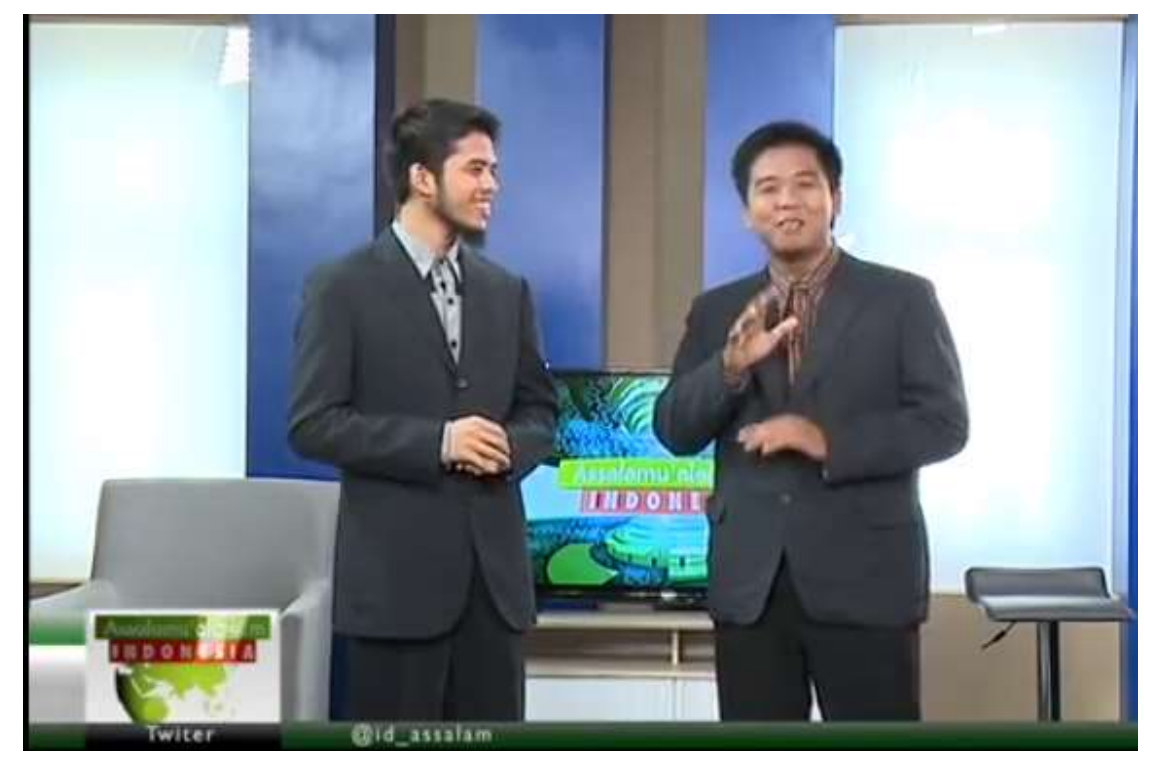

Gambar 4. Gimmick Program Acara Assalamualaikum Indonesia Episode Berdakwah Lewat Karya Film Pendek (Sumber : Capture Canel Youtube Salam Tv.2017)

Dari gambar 4 di atas, dapat dilihat kedua host telah melakukan gimmick untuk menghidupkan suasana agar penonton tidak merasa bosan. Meskipun demikian, gimmick yang dilakukan dianggap belum berhasil membuat penonton merasa tidak bosan karena kedua host tersebut masih terlihat kaku dalam melakukan gimmick tersebut dan tidak terlepas dari kesan formal. Sedangkan funfare sendiri digunakan pada saat berbincangbincang dengan bintang tamu yang ada. Elemen dari funfare sendiri menggambarkan mengenai puncak kemeriahan suatu program acara. Namun, pada program Assalamualaikum Indonesia tidak begitu tergambar puncak kemeriahan dari program tersebut. Semuanya terkesan lebih formal dengan memberikan informasi-informasi dari kedua host dan narasumber yang ada.

\section{Clip Hanger}

Clip Hanger merupakan suatu adegan yang diambangkan atau sengaja di gantung, selanjutnya di isi dengan Commercial Break. Clip hanger sangat penting dilakukan untuk menahan penonton agar melihat segmen selanjutnya dari program acara tersebut. 
Pada program Assalamualaikum Indonesia clip hanger tidak digunakan, seperti yang dapat dilihat untuk setiap segmen yang tayang semua disampaikan hingga selesai. Meskipun pada segmen kedua, salah satu host dengan sengaja tidak memberitahu bintang tamunya siapa namun hal tersebut belum mampu membuat penonton untuk mengganti tayangan tersebut.

\section{Tune and Bumper}

Tune atau opening tune merupakan kumpulan/cuplikan dari beberapa gambar atau komputer grafik yang terdapat pada awal program dimulai. Sedangkan Bumper merupakan penamaan dari suatu program drama atau non drama yang biasanya berada pada opening / closing program dan pada saat adanya commercial break. Program Assalamualaikum Indonesia juga mempunyai tune dan bumper pada setiap segmennya. Hal ini dapat dilihat setiap awal segmen dan juga di akhir segmen seperti pada gambar berikut:

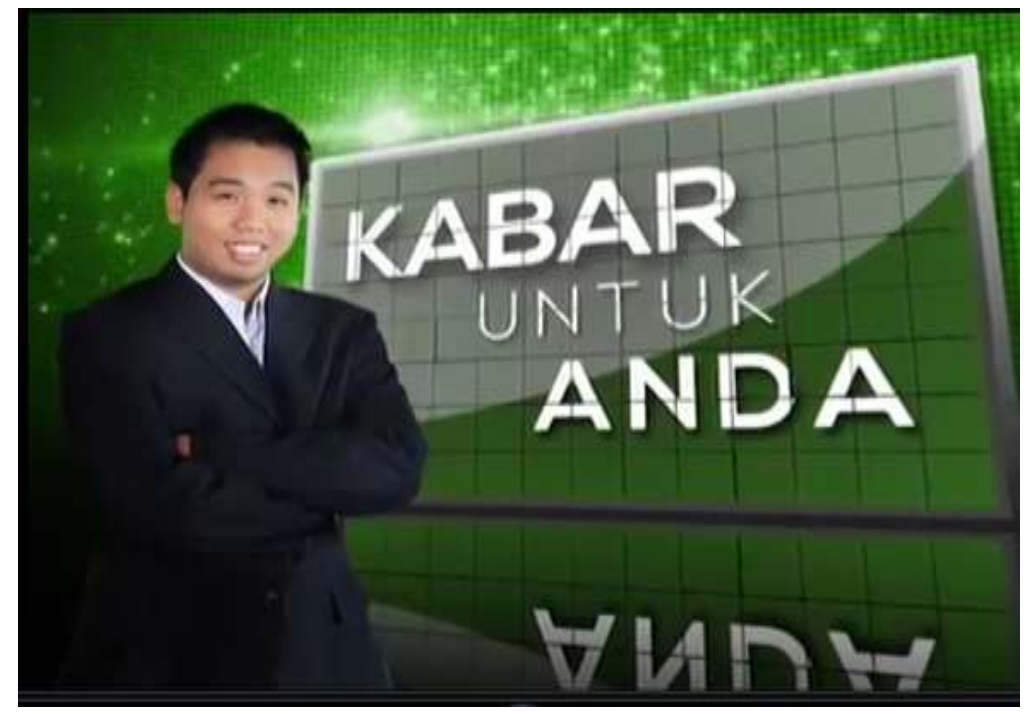

Gambar 5. Opening Tune Program Acara Assalamualaikum Indonesia Episode Berdakwah Lewat Karya Film Pendek (Sumber : Capture Canel Youtube Salam Tv.2017)

Gambar 5 di atas merupakan potongan dari bagian opening tune pada program Assalamualaikum Indonesia yang merupakan tatanan grafis komputer dan ditambahkan efek khusus serta adanya sound effect yaitu musik yang menjadi cirri khas program Assalamualaikum Indonesia. Selain itu, desain bumper in yang bertuliskan nama program untuk mengawali program acara muncul dengan menggunakan efek slide fade in serta diiringi dengan musik yang sama ketika opening dimulai. Kemudian bumper out digunakan untuk mengakhiri opening tersebut. Adapun bumper dari program Assalamualaikum Indonesia seperti berikut: 


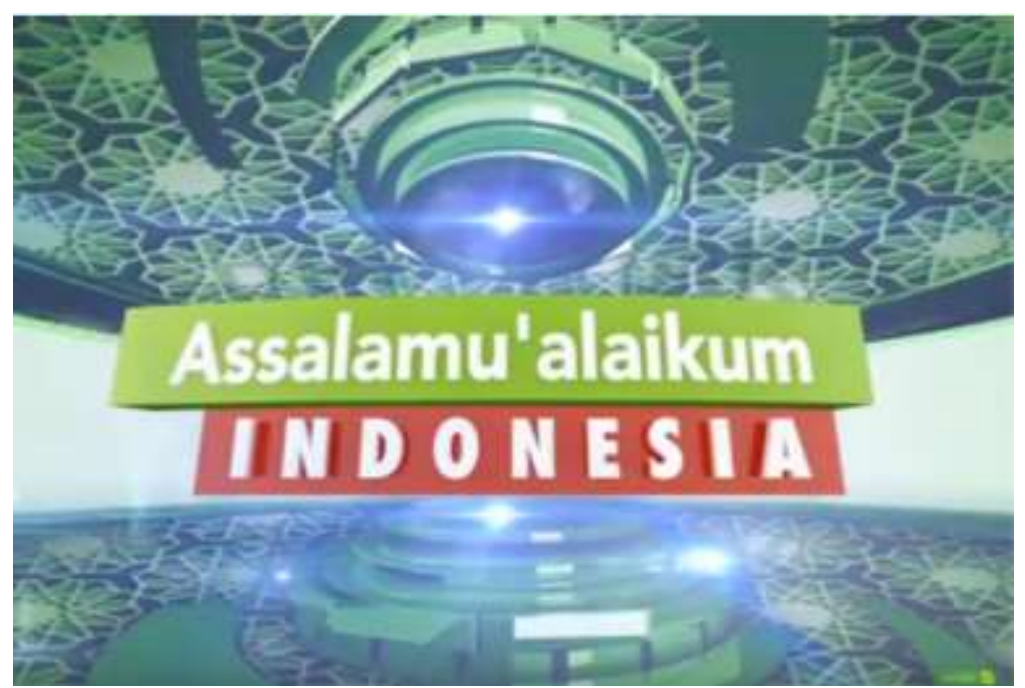

Gambar 6. Bumper Program Acara Assalamualaikum Indonesia Episode Berdakwah Lewat Karya Film Pendek

(Sumber : Capture Canel Youtube Salam Tv.2017)

\section{Penata Artistik}

Dalam setiap program acara memiliki set tata artistik yang berbeda-beda begitu juga dengan program acara Assalamualaikum Indonesia khususnya episode "Berdakwa Lewat Karya Film Pendek". Namun, pada program Assalamualaikum Indonesia tidak ditemui penataan artistik atau waredrobe yang berbeda pada setiap episodenya karena program acara tersebut bersetting di dalam ruangan serta berkonsep islami. Adapun tata artistik dan waredrrobe pada program acara Assalamualaikum Indonesia adalah sebagai berikut:

a. Setting tempat : lokasi dalam sebuah ruangan (indoor) dengan menampilkan suasana yang formal dan sopan.

b. Waredrobe : Waredrobe yang digunakan kedua host Assalamualaikum Indonesia adalah Jas berwarna hitam dengan kemeja didalamnya serta celana keper berwarna hitam dan sepatu. Sedangkan waredrop dari bintang tamu yaitu baju batik yang dipadukan dengan celana keper.

c. Properti : properti-properti yang digunakan untuk mengeset dekorasi ruangan yaitu pada awal segmen terlihat 1 sofa, televise, meja dan 1 kursi kafe yang digunakan oleh host sebelum bintang tamu datang. Setelah bintang tamu datang masih pada tempat yang sama namun terdapat sofa panjang yang disediakan untuk bintang tamu.

\section{Tata Busana}

Tata busana merupakan suatu hal yang penting untuk mendukung suatu program acara agar terlihat menarik. Tata busana biasanya disesuaikan dengan tema yang terdapat pada program acara tersebut. Pada program Assalamualaikum Indonesia tata busana yang digunakan terkesan formal dengan menggunakan pakaian jas, kemeja serta lengkap dengan sepatu. Hal tersebut menjelaskan kesan kesopanan sesuai dengan visi misi stasiun televisi Salam Tv yang berkonsep islami. Maka dari itu, konsep artistik yang digunakan disesuaikan dengan visi dari stasiun televisi tersebut termasuk konsep tata busana yang digunakan. 


\section{Musik atau Backsound}

Pada program Assalamualaikum Indonesia berlangsung, tidak terdapat musik atau backsound yang mengiringi 4 segmen dari program tersebut berlangsung. Musik hanya ada pada saat opening program dimulai dan juga pada diakhir segmen. Hal tersebut memungkinkan dilakukan agar informasi-informasi yang disampaikan jelas didengar oleh penonton. Akan tetapi, program acara tersebut dapat menimbulkan rasa bosan karena tidak adanya efek music atau becksound dalam jalannya program acara tersebut.

\section{Ritme dan Birama Acara}

Seperti Musik yang memerlukan intro, refrain, coda dan improfisasi. Dalam sebuah program acara sebenarnya ritme dan birama juga diperlukan untuk menghilangkan efek kejenuhan pada penonton dan menghindari penonton mengganti tayangan program acara tersebut. Namun demikian, tidak semua program acara menggunakan ritme dan birama untuk membangun mood penonton dalam suatu program acara seperti program Assalamualaikum Indonesia. Pada penjelesan sebelumnya, bahwa program Assalamualaikum Indonesia juga tidak menggunakan musik atau backsound. Ritme dan birama juga tidak pergunakan dalam program acara tersebut, hal ini memungkinkan terjadi karena program Assalamualaikum Indonesia adalah tayangan berbayar dan tidak semua masyarakat dapat menjangkaunya.

\section{General and Rehearsal}

General atau Rehearsal merupakan tahapan persiapan sebelum produksi suatu program acara dimulai. Program Assalamulaikum Indonesia juga melakukan persiapan sebelum melakukan tahapan produksi seperti set up lokasi, karena program Assalamualaikum Indonesia merupakan program yang dilakukan didalam studio maka para kru men-setting sebuah ruangan dengan konsep formal, santai dan lainnya. Selain itu, program Assalamualaikum Indonesia juga pasti melakukan riset baik itu riset melalui google atau media sosial atau riset secara langsung ke lapangan untuk mengetahui informasi atau berita apa saja yang sedang berkembang saat ini. Karena tidak dapat dihindari untuk menarik minat penonton maka tim kreatif harus menemukan informasi-informasi terupdate sehingga berita yang ditayangkan tidak ketinggalan.

Selain itu, program Assalamualaikum Indonesia juga menghadirkan narasumber yang mampu menginspirasi para penontonnya. Hal ini juga perlu melakukan riset terlebih dahulu mengenai narasumber yang akan dihadirkan, apakah narasumber tersebut layak atau tidak. General Rehearsal sendiri juga merupakan latihan yang dilakukan kepada seorang artis/narasumber/host yang terlibat dalam sebuah progam acara dan dilakukan sebelum produksi acara tersebut dilakukan. Hal tersebut dilakukan untuk menghindari pengulanganpengulangan take serta menghindari kesalahan-kesalahan pada saat produksi dilakukan.

\section{Interactive Program}

Program Assalamualaikum Indonesia juga mengembangkan kontennya dengan melibatkan partisipasi dari penonton yang melihat program tersebut. Akan tetapi, karena program Assalamualaikum Indonesia merupakan program yang tayangnya tidak live maka interactive program dilakukan melalui media sosial. Hal tersebut diperjelas pada saat host menyebutkan bahwa penonton yang aktif di media sosial dapat mengirimkan komentarnya melalui media sosial seperti twitter dan facebook serta penonton juga dapat langsung menikmati tayangan Asalamualaikum Indonesia melalui streaming youtube dan dapat 
langsung memberikan komentar-komentarnya pada akun youtube Salam Tv. Dengan demikian interactive program secara teidak langsung digunakan pada program Assalamualaikum Indonesia untuk menerima masukan-masukan yang diberikan oleh penontonnya.

\section{KESIMPULAN}

Sebuah program acara sangat penting mempertimbangkan strategi-strategi kreatif didalamnya untuk menarik minat penonton. Strategi kreatif juga dapat menjadi pusat perhatian dari sekian banyaknya program acara yang ada sehingga suatu program acara dapat bersaing dengan yang lainnya. Program Assalamualaikum Indonesia merupakan program acara dengan format talkshow. Secara umum program acara Assalamualaikum Indonesia belum menggunakan variasi konten pada setiap episodenya. Tetapi, program acara ini selalu memperhatikan dan menekankan informasi-informasi yang akan disampaikan pada penontonnya sehingga informasi tersebut dapat bermanfaat bagi penontonnya. Oleh karena program Assalamualaikum Indonesia hanya dapat dinikmati secara berbayar maka untuk dapat bersaing dengan program acara yang lainnya atau stasiun televisi lain. Program Assalamualaikum Indonesia dapat dinikmati melalui youtube sehingga program ini dapat menjangkau masyarakat luas.

Dari beberapa episode yang tayang pada program Assalamualaikum Indonesia. Penulis memilih episode "Berdakwah Lewat Karya Film Pendek" yang menghadirkan narasumber dari salah satu production house $(P H)$ yaitu Fisabilillah production. Konten yang disampaikan berbeda dengan konten yang lainnya seperti bagaimana berdakwah melalui sebuah film pendek. Dalam 13 elemen strategi kreatif dari buku Naratama yang digunakan peneliti untuk melihat proses kreatif pada program Assalamualaikum Indonesia yaitu target penonton, bahasa naskah, format acara, puncing line, gimmick dan funfare, clip hanger, tune \& bumper, penataan artistic, music \& fashion, ritme dan birama acara, log dan music track untuk ID tune, General Rehearsal, interactive program. Peneliti mendapatkan tidak semua strategi digunakan dalam program Assalamualaikum Indonesia untuk membangun proses kreatif, hal ini disesuaikan dengan konsep yang di usung oleh stasiun televisi Salam Tv yang berkonsep islami sehingga hal-hal yang memungkinkan diluar dari konsep islami tidak dipergunakan. Program Assalamualaikum Indonesia juga lebih cenderung atau menekankan pada penyampaian informasi-informasi yang bermanfaat bagi para penonton meskipun hal tersebut membuat program tersebut terasa membosankan. Selain itu, tata busana yang digunakan juga sangat formal sehingga tidak mencirikan identitas kota medan sendiri. Sebaiknya, tim kreatif dapat mempertimbangkan hal-hal yang menjadi ciri khas program acara tersebut dan memadukan dengan ciri khas kota Medan sehingga program acara dapat lebih dekat dengan pemirsa yang melihat dirumah.

\section{DAFTAR PUSAKA}

[1] Febriana, Dina. 2013. Proses Produksi Program Talk Show "Redaksi 8" Pada Televisi Lokal Tepian TV Samarinda. E Jurnal Ilmu Komunikasi

[2] Hilmawan, Pratista. 2008. Memahami Film, Cetakan 1

[3] Morissan. 2008. Manajemen Media Penyiaran Strategi Mengeloloa Radio dan Televisi. Jakarta: Kencana 
[4] Meleong, Lexy J. 2013. Metodologi Penelitian Kualitatif. Bandung : PT Remaja Rosdakarya.

[5] Naratama. 2013. Menjadi Sutradara Televisi. Jakarta : PT Grasindo.

[6] Sugiono. 2012. Memahami Penelitian Kualitatif. Bandung: AlfabetaJurnal Teknologi Informasi Dan Komunikasi Ugm. 